\title{
THE MORPHOGENESIS OF CIRCUMVALLATE PAPILLAE AND THE DIFFERENTIATION OF TASTE BUDS IN THE PIG AT 41 TO 64 DAYS OF PRENATAL DEVELOPMENT
}

\author{
F. TICHÝ \\ Department of Anatomy, Histology and Embryology \\ University of Veterinary Science, 61242 Brno
}

Received February 6, 1990

\begin{abstract}
Tichý, F.: The Morphogenesis of Circumvallate Papillae and the Differentiation of Taste Buds in the Pig at 41 to 64 Days of Prenatal Development. Acta vet. Brno, 60, 1991: 99-100.

Samples of tongues collected from porcine foetuses at $41,44,50,53,57$ and 64 days after fertilization were examined for the appearance and development of surface lingual structures. At each of the stages studied, the morphogenesis of circumvallate papillae and the differentiation of taste buds were recorded. Attention was paid to the formation of gustatory glands and their ducts and to the development of the furrow encircling the circumvallate papilla. The differentiation of the other types of lingual papillae was also studied.

The formation of taste buds in the epithelium coincided with the shape differentiation of circumvallate papillae. The buds appeared first in the dorsal surface epithelium and later in the wall epithelium. The number of differentiating buds within one papilla increased with foetal age. Different cell types composing the taste bud could be distinguished soon after the bud was formed.

The circumvallate papilla was either formed as a unified structure of typical appearance or had first a composite base later giving rise, by fusion of its segments, to the typical papilla.

The other lingual papillae developed at later stages than the circumvallate papillae.

Tongue, circumvallate papilla, taste bud, differentiation, pig
\end{abstract}

The structure, function and distribution of taste buds were studied as early as in the second half of the last century. The first observations were made in fish (Schulze 1863), then in mammals (Loven 1868; Schwalbe 1868). The general information on the structure of the taste organ in some species of laboratory mammals and in man were obtained by means of light microscopy at the beginning of this century (Kolmer 1910; Retzius 1912; Heidenhain 1914).

Progress in understanding the mechanism of taste perception occurred with the advent of techniques allowing observations at the ultrastructural level. Many of data on the submicroscopic structure of taste buds together with characterization of their cell types (Beidler and S mallman 1965; De Lorenzo 1958; Engstrom and Rytzner 1956; Fahrmann and Schuchard 1967; Farbman 1965a; Farbman and Vonkers 1971; Fujimoto and Murray 1970; Murray 1969, 1971, 1973; Murray and Murray 1960, 1967, 1970; Murray et al. 1969; Takeda and Hoshino 1975; Trujillo-Cenoz 1957; U ga 1966, 1969) have provided the grounds for the development of biochemical and physiological methods for investigation of taste perception (Beidler 1970; De Han and Graziadei 1971, 1973; Desgranges 1966; Hirata and Nada 1975; Spoendlin 1970; Takeda 1976; Beauchamp and Cowart 1986). All these studies have contributed significantly to the understanding of processing and transport of taste stimuli within the bud. The most important information and methods of investigation have been reviewed and presented in textbooks (Cormack 1984; Banks 1981; Smolich and Michael 1985; Rooss and Reith 1985). 
The development of the taste organ in the lingual epithelium is well recorded in both man and various mammalian species (Beidler and Smallman 1965; Farbman 1965b, 1971; Takeda 1972). None of the relevant studies, however, has been concerned with the stages of ontogenic development or has paid attention to the changes occurring during development of the gustatory receptor. Our earlier study (Tichý and Cerný 1987) described the differentiation of taste buds at selected stages of ontogeny in sheep. This paper will deal with the formation, development and distribution of the taste buds and their functionally and topographically related structures in the prenatal pig.

\section{Materials and Methods}

Samples were collected from the tongues of porcine foetuses at 41, 44, 50, 53, 57 and 64 days after fertilization. The age of foetuses was estimated by their crown-rump lenght according to Evans and Sack (1973).

Three pigs were sampled in each age category. The material was excised from the tongues in the following areas: junction between the body and root, lateral part of the root, apical dorsum linguae. The samples were fixed immediately in $10 \%$ neutral formaldehyde. To prevent artifacts ensuing from a sudden dehydration of embryonic tissues rich in water, the graded alcohol series, starting with $10 \%$ alcohol, increased by $10 \%$ in each subsequent bath.

The sections were routinely stained with haematoxylin and eosin. To intensify the visualization of selected structures, the impregnation technique according to Gomori and nuclear red staining were used. Some of the sections were stained with the green trichrome reagent.

\section{Results}

Lingual mucosa at 41 days of foetal age (Fig. 1, Plate I, at the end of the volume)

The mucosal surface of the dorsum linguae was uneven. Frequent dome-shaped protrusions, the anlagen (rudiments) of papillae, could be seen along the lateral margins of the tongue. They were more prominent in the caudal regions, particularly at the junction of the body and root of the tongue.

The mucosa was covered with markedly stratified epithelium. It consisted of 2 to 3 lower layers, in which cells with rounded hyperchromatic nuclei were arranged in a palisade-like manner, and an upper layer of poorly-stained cells irregular in shape and size. The lower layer cells, distinctly smaller than the upper layer ones, constituted the lower half of the epithelium; "while the other half was made of only one layer of light, large cells. The upper layer was markedly thinner above the dome-like protrusions; in some instances it was even missing. The lingual epithelium had a uniform appearance all over the mucosal surface without any changes indicating the onset of taste bud formation.

A distinct basement membrane separated the epithelium from the layer of mucosal connective tissue containing numerous blood vessels. This extended against the epithelium forming the stromata of primitive papillae. Below these, connective tissue increased in density and began to organize which was a commencement of the aponeurosis linguae.

Lingual mucosa at 44 days of foetal age (Fig. 2, Plate I)

The dome-like protrusions evident on the lingual surface in the previous period were masked completely with proliferating epithelial cells; which gave the mucosal surface a mildly undulating appearance.

Cross-sections through the lingual mucosa showed distinct anlagen of circumvallate papillae which were marked with compact cell bands preceding the formation of a furrow around each papilla. No anlagen of the other types of lingual papillae were laid at this stage.

The epithelium of the lingual surface, similarly to the previous period, had 
two parts: the lower layer consisted of several strata of well-stained cells, the upper layer was made up of one or two strata of light, large, irregular cells. These poorly-stained cells produced the cell bands marking the extent and localization of the future encircling furrow.

In the epithelium of the dorsum linguae in the close vicinity of the cell bands, the lower epithelial layer included cells differing by their elongated shape and low intensity of staining. These cells extended down to the basement membrane and, in cross-sections, were bordered by pairs of cells with dark elongated nuclei.

The structure of the musocal connective tissue was markedly denser and more vascularized than in the previous period. The rudiment of the aponeurosis linguae was also more distinct.

Lingual mucosa at 50 days of foetal age (Figs 3, 4, Plate II)

At the lateral margins of the dorsum linguae, the lingual mucosa showed large disc-shaped elevations markedly protruding above the surface at the junction between the body and root of the tongue.

It could be seen in cross-sections that the discs were the anlagen of circumvallate papillae; they had already attained a typical shape but had not yet developed the encircling furrows. Their underlying cell bands, however, were found to run deeply into the connective tissue of the lamina propria mucosae. With their bottom part they penetrated under the base of the circumvallate papilla, while their terminal part produced fork-like extensions later developing into ducts of the gustatory glands. The other types of lingual papillae were observed only as mild protrusions of the lingual mucosa.

The lingual epithelium did not differ in structure from that of the previous age stzge. However, its thickness was greater due to an increased number of layers of poorly-stained polyedric surface cells.

The dorsal surface of the anlagen of circumvallate papillae showed the epithelium with taste buds at different stages of differentiation. These presented most frequently as cell clusters slightly exceeding in height the basal epithelial layer and easily discernible by less intense staining. All the cells involved in the commencement of taste buds at this stage were uniform in appearance. Cells of the basal epithelial layer attached to the anlagen of the taste buds attained a spindle-like shape; this was accompanied by similar morphological changes in their nuclei.

The rudiment of the aponeurosis linguae was more marked than in the previous age category, but under the bases of circumvallate papillae the thickening of connective tissue could not be seen.

Lingual mucosa at 53 days of foetal age (Fig. 5, 6, Plate III)

The epithelium of the dorsum linguae at this stage was characterized by numerous protuberances, varying in size and shape, and shallow and narrow depressions. The protuberances were the future papillae not yet differentiated in shape, the depressions indicated the separation of the papillae from the surrounding tissue. The epitheliaum did not differ in structure from that seen in the previous period.

A cross section through the dorsum linguae demonstrated more frequent and larger anlagen of papillae than in the 50-day-old foetus. The picture, however, did not yet allow us to distinguish between different types of lingual papillae with the exception of the circumvallate papillae. 
These papillae had a typical configuration and, because of their size, they became the most conspicuous formations on the lingual epithelium. Although the encircling furrow was not completed, its basis in the form of a cell band extended deeply into the mucosal connective tissue. In the cell band, a narrow groove began to form from the epithelial surface down. At this stage it ran down one third of the total cell band height. Its lower part divided into thin projections directed towards the aponeurosis linguae rudiment. These would later constitute the gustatory gland ducts.

Taste buds in various stages of differentiation were observed in the epithelium of the dorsal surface and walls of the circumvallate papilla as well as in the epithelial basis of the encircling furrow. Most frequently they presented as round cell clusters which did not reach as far as the epithelial surface but were covered with one or two layers of cells. The taste bud cells included cells with dark nuclei and those with light nuclei. A clear cut between the sensory and supporting cells could not be made by light microscopic observations at this stage.

The connective tissue of lamina propria mucosae was rich in blood vessels. The aponeurosis linguae rudiment had the same appearance as in the previous period.

\section{Lingual mucosa at 57 days of foetal age (Figs 7 to 11, Plates IV, V and VI)}

The tongue surface differed markedly from that seen in the lower age category. The mucosa within the dorsum linguae appeared to consist of numerous big, separated papillae still undifferentiated in shape. Occasionally the separation was only suggested. The lateral surface of the tongue had a mildly undulating appearance.

The most conspicuous structures seen in cross-sections were the rapidly developing circumvallate papillae. They had a typical shape and were bordered by deeply extending epithelial bands. These contained round hollow spaces of different volumes seen both near the surface and in the basal farts of 1 he cell band. The spaces near the surface were elongated and separated with one or two long epithelial cells. The basal spaces were narrow and markedly smaller. The bases of the epithelial bands were divided into many developing ducts of the gustatory gland which ran deep into the differentiating muscular tongue base. Their terminal portions separated rounded formations, later presenting as secretory components of the gland. In cross-sections the ducts at this stage showed lumina.

At this foetal age, another form of the circumvallate papilla was regularly observed. These atypical papillae composed of several segments were surrounded with solid cell bands whose lower parts branched into ducts of the gustatory gland. The bigger segments were always found in the centre while their size decreased close to the periphery of this composite anlagen of the circumvallate papilla. These composite anlagen were observed on the tongue of one and the same foetus together with the usual anlagen of circumvallate papillae described above.

Taste buds were generally found on the circumvallate papillae showing the typical differentiation. They occurred in the epithelium of the dorsal surface and of the walls. They had a characteristic appearance and were never found reaching the surface of the epithelium. They included nuclei of two types: hyperchromatic nuclei, smaller in size and oval in shape, and nuclei with diffuse chromatin, larger in size and also val in shape. 
The anlagen of the atypical papillae, particularly in the epithelium of the dorsal surfaces of the segments, also showed differentiating taste buds. Their appearance was reminiscent of that observed in the previous age category, where it was not possible to differentiate various cell types on the basis of their nucleus characteristics.

Taste buds at the initial stage of differentiation were also recorded on the primitive anlagen of foliate papillae situated on the lateral surface of the tongue. They presented as cell clusters on the top of the papillary anlage. They did not extend beyond the basal epithelial layer and from the connective tissue of the lamina propria mucosae were separated with a fold of the basement membrane.

The cells of the basal epithelial layer which were in the close vicinity of the taste bud were elongated, with rod-shaped nuclei. Changes in shape found in cells attached to the taste bud were more marked with increasing bud differentiation.

Anlagen of secretory compartments of the gll. gustatoriae were found in the layer of mucosal connective tissue and also deep among fasciculi of the developing tongue wasculature. They presented as oval cell aggregations of different size.

At the border of the lamina propria mucosae and the muscle tissue, a thick dense layer of the aponeurosis linguae was observed. It was not seen under the bases of the circumvallate papillae.

\section{Lingual mucosa at 64 days of foetal age (Figs 12 to 16, Plates VI, VII, VIII).}

The mucosal surface of the dorsum linguae bore numerous papillae much bigger than those seen in the previous period. Apart from circumvallate papillae, however, they were not differentiated in terms of shape. The lateral surface of the lingual mucosa showed elevations indicating the formation of foliate papillae.

The circumvallate papillae presented as large formations separated from the surrounding tissue by well defined furrows. Their dorsal surface was seen as a pattern of depressions and elevations. A cross-section through a depression showed that a thin cell band, involving a lumen, extended from its bottom downward into the lingual musculature to be connected with secretory regions of the gustatory gland. These ducts opening onto the dorsal surface of the circumvallate papillae had lumina of varying width but never as wide as the true orifices of the gustatory gland.

The lingual epithelium on the dorsal surface of the circumvallate papillae had the appearance of a mature papilla with one or two surface layers of flat cells showing signs of keratinization. The epithelium lining the furrow around the circumvallate papilla grew thinner toward the furrow bottom. The epithelium on the rest of lingual mucosa was characterized by a distinct surface layer of poorly-staining large polyedric cells, as at the previous stage.

The anlagen of foliate papillae present on the lateral surfaces of the tongue were not separated distinctly from the surrounding tissue. When sectioned transversally, they presented as cylinders of connective tissue covered with a thick stratified epithelium composed of light polyedric cells. The germinative part of the epithelium was limited to one or two layers of small but well-stained cells with oval hyperchromatic nuclei.

Taste buds were observed in the epithelium on the dorsal surface and in the walls of circumvallate papillae. Taste buds in the process of differentiation were also present on the dorsal surface of the anlagen of foliate papillae.

The taste buds observed in the epithelium of circumvallate papillae had a ty- 
pical shape and consisted of two well differentiated cell types. Cells with nuclei containing less chromatin were more numerous than those with hyperchromatic nuclei. Epithelial cells adjoining the taste bud were markedly increased in length and made the outer boundary of the bud. The apical end of the bud was overlaid with one or two layers of flat cells preventing communication with the surface.

The taste buds on foliate papillae, still in the process of differentiation, appeared as cell clusters with the bases extending beyond the lower epithelial margin into the lamina propria mucosae, from which they were separated with basement membrane folds. At this stage of differentiation it was possible to distinguish cells with hyperchromatic nuclei from those with light nuclei.

The lamina propria mucosae and the aponeurosis linguae had similar structures to those found in the previous age group.

\section{Discussion}

The picture of the lingual mucosa with its structures and components is well documented by both light and electron microscopic studies. Similarly, a lot of data have been accumulated on taste buds, giving, comprehensive information on their shape, size, ultrastructure, the mechanism of development and principles of taste perception. The cell types constituting the taste bud, and their ultrastructure and function have also received attention.

Considerably less information has been reported on the processes related to the commencement of various mucosal structures of the tongue and their further development in the foetuses of domestic animals. Particularly incomplete are data concerning the sequence of events leading to the development, differentiation and distribution of taste buds and their relation to the development of lingual papillae.

In the porcine foetus, the most significant period for morphological changes in the lingual mucosa seems to be from day 50 to day 64 . This stage is marked by a rapid development of various components of the lingual mucosa; the anlagen of papillae are formed and taste buds are iniciated.

In the surface lingual epithelium of the porcine foetus, the first signs of differentiation are apparent between day 41 and day 44 . It is 10 days earlier than in ovine foetuses (Tichý and Černý 1987). Epithelial cells proliferate at a high rate, which makes the uneven appearance of the dorsal surface at day 41 become smooth at day 44 . At the same time growing epithelial bands penetrate into the mucosal connective tissue forming the first, not too distinct outlines of the future circumvallate papillae. At 44 days the basal epithelial layer of the lingual mucosa within the anlages of papillae contains cells with poorly-stained cytoplasm; these are not seen in the ovine foetus of the same age (Tichý and Černý 1987). The cells are found single or in small clusters and are thought to be implemented in the initial stages of taste bud formation. Their adjoining cells change in morphology; they became rod-shaped and so do their nuclei. The slender cells encompass the light cells; they will presumably give rise to one of the cell types constituting the taste bud. Some authors (Beidler and Smallmann 1965; Farbman 1965a) regard them as a stock of cellular material which serves to supply cells to the developing taste bud. Similar arrangements of epithelial cells adjoining the developing taste bud were, in more pronounced forms, seen at the other stages of prenatal 
development, which implies that all cell types are continually supplied (Farbmann 1971; Whiteside 1927). At 50 days the anlagen of taste buds are distinctly laid. They are formed by cluster of light cells which do not extend beyond the basal epithelial layer. In the light microscope they have a uniform appearance. At this stage it was not possible to distinguish cell types reported in electron-microscopic studies (De Lorenzo 1958; Engstrom and Rytzner 1956; Fahrman and Schuchard 1967; Farbman 1965, 1971; Graziadei and De Han 1971; Murray and Murray 1960, 1967, 1970 and others). The buds at this stage are localized to the dorsal surface of the anlagen of circumvallate papillae. It is suggested that this localization is also typical for the early stages of development of the lingual mucosa in other domestic animals (Tichý and Černý 1987). In the wall epithelium of the circumvallate papillae, the taste buds appear later, at 53 days of foetal age, but at greater numbers. As suggested by some authors, the taste bud differentiation is initiated by a contact of epithelial cells with a nerve fibre (Desgranges 1966; Farbman 1965a, b; Fujimoto and Murray 1970; Kurosumi and Kurosumi 1969; Munger 1965; Spoendlin 1970; Takeda and Hoshino 1975). The site of contact determines the location of the future bud (Takeda 1976). The presence of taste buds in the epithelium is, in our opinion, directly related to the development and growth of the anlagen of circumvallate papillae (Tichý and Černý 1987). From day 57 on, the circumvallate papilla anlagen undergo marked differentiation, while the occurrence of taste buds on their dorsal surface is being reduced, so that, from day $64 \mathrm{on}$, they occur only occasionally. It is of interest that taste buds begin to from in the lingual epithelium at the time when circumvallate papillae start to differentiate in shape. In contrast to the findings published earlier (Tichý and Černý 1987) in porcine foetuses the commencement of differentiation of both the papilla and the bud occur at the same time.

Taste buds on the anlagen of foliate papillae differentiate later than those on circumvallate papillae, i. e. from day 57 . They appear on the dorsal surface of the foliate papilla at the time of its commencement. If the view that the differentiation of taste buds is initiated by contact of epithelial cells with a nerve fibre (Farbman 1965; Murray and Murray 1967; Takeda 1976) is correct then the area of developing circumvallate papillae is supplied with nerves earlier than the lateral parts bearing the anlagen of foliate papillae. This is also evidenced by our finding that in each period the stage of differentiation of the epithelium was higher on the dorsum linguae than on the lateral surfaces.

The differentiation of cell types inside the taste bud can be seen from day 53, when the occurrence of two cell types differing in the appearance of nuclei was first recorded. This seems to be the early period of development of sensory and supportive cells. The ultrastructure of this and other types of cells composing the taste bud was documented by many electron microscopic studies (De Lorenzo 1958; Farbman 1965a, b; Gray and Watkins 1965; Graziadei 1969; Murray 1971, 1973; Murray and Murray 1969; Takeda 1972; Takeda and Hoshino 1975; Trujillo-Cenoz 1957; Uga 1966, 1969).

In the period between the 50th and 64th days of prenatal development, the epithelium of the foundations of circumvallate papillae shows taste buds at various stages of differentiation in terms of shape, size and structure. First they look like cell clusters located within the basal epithelial layer. In some instances they penetrate below the epithelial base into the layer of mucosal connective tissue, from which they are separated by a fold of the basement membrane. 
On day 57 the developing taste buds reach as far as the surface layer of epithelium but on day 64 they still do not communicate with the epithelial surface. This implies that in this period the bud differentiates only in structure while maturation leading to the definite size and localization occurs at the following stages.

An unexpected finding was the detection of composite anlagen of circumvallate papillae on day 57. Their occurrence was regular along with that of typical circumvallate papillae. At 64 days of prenatal development, however, the anlagen of circumvallate papillae presented as typical uniform structures. It can be speculated whether the composite anlagen will have any effect on the appearance of circumvallate papillae in the adult animal whether they occur only as an insignificant anomaly in the course of development. We favour the concept of involvement of composite papillary anlagen in the final appearance of the circumvallate papillae because in the pig these papillae are know to have a variety of shapes and sizes. In the spaces between segments of the composite anlage of the circumvallate papilla, the gll. gustatoriae ducts are formed; they persist even after the segments fuse into a unified anlage of the papilla at 64 days. Our observations show that the ducts open at the bottom of depressions on the dorsal surface of the circumvallate papilla. These cannot be considered the definite ducts because their lumina are noticcebly smaller and they, themselves, disappear ot the later stages.

The finding of hollow spaces among the cells of the epithelial band, later the furrow encircling the papilla, was also unusual. They are first seen on day 57 and are accounted for by changes in the compact band, which leads to the formation of the encircling furrow.

From day 50 on, it was observed that the continuity of the aponeurosis linguae under the anlagen of circumvallate papillae was broken. The absence of the aponeurosis linguae in these regions may be explained as enabling the developing ducts of the gustatory gland to grow downward.

Since no similar report on the development and maturation of the lingual mucosa of the prenatal period reported in this paper has been found in the literature, the observations described here can be considered an original contribution to this field investigation.

\section{Conclusions}

This paper describes the differentiation of certain structures of the lingual mucosa in the pig at 41 to 64 days of foetal age. Attention was focused on the morphogenesis of circumvallate papillae, the differentiation and localization of taste buds in the lingual epithelium and the development of some other related structures. The following conclusions have been drawn:

1. Taste buds appear in the lingual epithelium first on the dorsal surface of developing circumvallate papillae at 50 days of prenatal development. However, the first signs of their differentiation can be recognized as early as on day 44 .

2. Taste buds begin to form on the anlagen of foliate papillae on day 57 .

3. A considerable increase in the amount of taste buds in the epithelium of circumvallate papillae is recorded from day 53.

4. Taste buds are at first limited to the dorsal epithelial surface of the circumvallate papillae. At 53 days they appear in the wall epithelium involved in the basis of the encircling furrow. From day 64 on, the occurrence of taste buds on the dorsal surface of circumvallate papillae is a rare finding. 
5. The differentiation of cell types inside the taste bud can be recorded from the 53rd day of foetal development.

6. Taste buds do not reach up to the surface of epithelium during the period described in this paper.

7. The anlagen of circumvallate papillae are laid down at 44 days of foetal age and attain their appearance at 64 days. The composite anlagen of circumvallate papillae are first seen on day 57, but by day 64 the circumvallate papillae is a unified structure.

8. The ducts of gustatory glands are commenced at 53 days and the first lumina can be observed on day 57. At that time the lamina propria mucosae and lingual musculature show the first signs of secretory regions of the glands. The ducts are formed between segments of the composite anlagen of circumvallate papillae at 57 days and persist even after the segments disappear in the unified bases of the papillae at 64 days.

9. The furrow encircling the circumvallate papillae is started when cells of the epithelial band begin to move apart at 53 days. On day 57, spaces among cells appear and the cleft is completed at 64 days.

10. Foliate papillae begin to differentiate at 57 days.

11. The rudiment of the aponeurosis linguae is indicated at 41 days and at 50 days it presents as a compact layer of connective tissue reduced under the bases of circumvallate papillae.

\section{Morfogeneze hrazené papily a diferenciace chutových pohárků fetu prasete v období 41. -64 . dne}

$\mathrm{V}$ práci je věnována pozornost vzniku, vývoji a morfogenezi hrazených papil a diferenciaci chutových pohárků $v$ epitelu jazyka prasete od 41. do 64. dne intrauterinniho vývoje.

Odebrány byly vzorky jazyka prasečích fetů ve stáŕi 41, 44, 50, 53, 57 a 64 dnů po koncepci. Byl sledován vznik, vývoj a vzhled povrchových struktur sliznice jazyka $\mathrm{v}$ jednotlivých etapách vývoje se zřetelem na morfogenezi hrazených papil a diferenciaci chutových pohárků v jejich epitelu. Současnè byla pozornost zaměřena na vývoj a utváření gll. gustatoriae a jejich vývodů, vznik brázdy ohraničující hrazenou papilu a diferenciaci dalších typů jazykových papil.

Chutové pohárky se $\mathrm{v}$ epitelu zakládají současně $\mathrm{s}$ tvarovou diferenciací hrazené papily. Nejprve jsou lokalizovány $\mathrm{v}$ epitelu dorsální plochy hrazené papily, $\mathrm{v}$ epitelu stěn se objevují teprve později. Postupně se zvyšuje počet diferencujících se pohárků v rozsahu jedné hrazené papily. $K$ diferenciaci buněk chutového pohárku na jednotlivé typy dochází krátce po jeho vzniku.

Hrazené papily se zakládají buđ jako jednotný útvar typického vzhledu, nebo je základ mnohočetný, a papila pak vzniká postupným splynutím jednotlivých dílčích základů. Vývody gll. gustatoriae luminizují současně se vznikem obkružující brázdy hrazené papily.

Ostatní typy jazykových papil vznikají později než papila hrazená. 


\section{Морфогенез желобоватого сосочка и дифференциация вкүсовых сосочков плода свиньи в период 41- 64 сүток}

В работе уделено внимание возникновению, развитию и морфогенезу желобоватых сосочков и дифференцеации вкусовых сосочков В эпителии языка поросят, начиная с 41 и кончая 64 днем внутриутробной жизни.

Отбирали пробы языка плодов поросят в возрасте 41, 44, 50, 53, 57 и 64 сүток после зачатия. Исследовали возникновение, развитие и внешний вид поверхностных структур слизистой языка на отдельных этапах развития с учетом морфогенеза желобоватых сосочков и дифференциации вкусовых сосочков в его эпителии. Внимание было одновременно направлено на развитие и формирование gll. gustatoriae и их протоков, возникновению борозды, ограничивающей желобоватый сосочек, и дифференциации других типов сосочков языка.

Вкусовые сосочки в эпителии являются одновременно с дифференциацией формы основой желобоватого сосочка. Сперва они находятся в эпителии дорсальной поверхности желобоватого сосочка, в эпителии стенок они появляются несколько позже. Постепенно увеличивается численность дифференцирующихся сосочков в пределах оного желобоватого сосочка. Дифференциация клеток вкусового сосочка на отдельные типы происходит вскоре после его возникновения.

Основой желобоватых сосочков являются единые характерного вида формирования или многочисленные формации; папилла впоследствии возникает постепенным слиянием отдельных единичных основ. Протоки gll. gustatoriae выходят одновременно с возникновением окружающей борозды желобоватого сосочка.

Остальные типы сосочков языка возникают позже желобоватого сосочка.

\section{References}

BANKS, W. J.: Applied veterinary histology. Williams and Wilkins, Baltimore, London, 1981, pp. $374-376$

BEACHAMP, G. K.-COWART, B. J.: Development of Sweet Taste Sweetness. Ilsi human nutrition Reviews, Symp. on Sweetness, Geneva, Switzerland, May 21-23, 1986: 127-130

BEIDLER, J. M.-SMALLMAN, R. L.: Reneval of cells within taste buds. J. Cell Biol., 27, 1965: $263-272$

BEIDLER, J. M.: Physiological properties of mammalian taste receptors. In: Taste and smell in vertebrates. Wolstenholme and Knight, eds. Ciba Found. Syup. London, J. \& A. Churchill, 1970, pp. $51-67$

CORMACK, D. H.: Introduction to Histology. J. B. Lippincott Company Philadelphia, London,

New York, 1984, pp. 287-289.

DE HAN, R.-GRAZIADEI, P.P.C.: Functional anatomy of frog's taste organs. Experientia, 27, 1971: $823-826$.

DE HAN, R.-GRAZIADEI, P.P.C.: The innervation of frog's taste organ. "A histochemical study." Life Sci., 13, 1973: 1435-1449

DE LORENZO, A. J.: Electron microscopic observation on the taste buds of the rabbit. J. Biophysic. Biochemic. Cytol., 4, 1958: 143-150

DESGRANGES, J. C.: Sur la double innervation des cellules sensorielles des bourgeons du gout. des barbillons du Poisson-chat. C. r. Acad. Sci. (Paris), 263, 1966: 1103-1106

ENGSTRÖM, H. - RYTZNER, C.: The fine structure of taste buds and taste fibers. Ann. Otol. (St. Louis), 65, 1956: $361-375$ 
EVANS, H. E. - SNACK, W. O.: Prenatal development of domestic laboratory mammals. Growth curves, external features and selected references Zbl. Vet. Med. C 2, 1973: 11 - 45

FÄHRMANN, W.-SCHUCHARDT, E.: Licht- und electronenmikroskopische Befunde an den Geschmacksknospen der Axolotlzunge. Experientia, 23, 1967: 657-659

FARBMAN, A. I.: Fine structure of the taste bud. J. Ultrastruct. Res., 12, 1965a: $328-350$

FARBMAN, A. I.: Electron microscope study of the developing taste bud in rat fungiform papilla. Develop. Biol. 11, 1965b: 110-135

FARBMAN, A. I.: Development of the taste bud. In: L. M. Beidler (Ed.) Handbook of sensory Physiology, Vol. IV., Chemical Senses, Part 2, Springer, New York, 1971, pp. 51-62

FARBMAN, A. I. - YONKERS, J. D.: Fine structure of the taste bud in the mud puppy, Necturus maculosus. Amer. J. Anat., 131, 1971: 353-370

FUJIMOTO, S. - MURRAY, R. G.: Fine structure of degeneration and regeneration in denervated rabbit vallate taste buds. Anat. Rec., 168, 1970:393-414

GRAY, E. G. - WATKINS, K. C.: Electron microscopy of taste buds of the rat. Z. Zellforsch., 66, 1965: 583-595

GRAZIADEI, P.P.C.: The ultrastructure of vertebrate taste buds. In: (ed. by) C. Pfaffmann: Olfaction and taste, New York, Rockefeller University, 1969, pp. 315-330

GRAZIADEI, P.P.C.-DE HAN, R. S.: The ultrastructure of frog's taste organs. Acta anat., 80, 1971: 563-603

HEIDENHAIN, M.: Über die Sinnesfelder und die Geschmacksknospen der papilla foliata des Kaninchens. Arch. mikr. Anat., 85, 1914: 365-479

HIRATA, K. - NADA, O.: A monoamine in the gustatory cell of the frog's taste organ. Cell Tiss. Res., 159, 1975: 101-108

KOLMER, W.: Ưber Strukturen im Epithel des Sinnesorgane. Anat. Anz., 36, 1910: 281 - 299

KUROSUMI, K.-KUROSUMI, U.-SUZUKI, H.: Fine structures of Merkel cells and associated nerve fibers in the epidermis of certain mammalian species. Arch. histol. jap., 30, 1969: $295-313$

LOVEN, D.: Beiträge zur Kenntniss von Bau der Geschmackswärzchen der Zunge. Arch. mikr. Anat., 4, 1868: 96-154

MUNGER, B. L.: The intraepidermal innervation of the snout skin of the opossum. A light and electron microscope study, with observations on the nature of Merkel's Tastzellen. J. Cell Biol., 26, 1965: 79-97

MURRAY, R. G.: Cell tapes in rabbit taste buds. In: Olfaction and taste III, Pfaffman, rd. New York, Rockefeller Univ. Press, 1969, pp. 331-344

MURRAY, R. G.: Ultrastructure of taste receptors. In: Handbook of sensory physiology, vol. IV Chemical senses, part 2 Taste, Beidler, ed. Berlin-Heidelberg-New York: Springer, 1971, pp. $31-50$

MURRAY, R. G.: The structure of taste buds. In: Ultrastucture of sensory organ, vol. 1, Friedman, ed. Amsterdam: North Holland, 1973, pp. 1-81

MURRAY, R. G. - MURRAY, A.: The fine structure of the taste buds of Rhesus and Cynomolgus monkeys. Ant. Rec, 138, 1960: 211-233

MURRAY, R. G.-MURRAY, A.: Fine structure of taste buds of rabbit foliate papillae. J. Ultrastruct. Res., 19, 1967: 327-353

MURRAY, R. G.-MURRAY, A.: The anatomy and ultrastructure of taste endings. In: (ed. by) G. E. W. Wolstenholme and J. Knight: Taste and smell in vertebrates. London, J. and A. Churchil, 1970, pp. 3-30

MURRAY, R. G. - MURRAY, A.-FUJIMOTO, S.: Fine structure of gustatory cells in rabbit taste buds. J. Ultrastruct. Res., 27, 1969: 444-461

RETZIUS, G.: Zur Kenntniss des Geschmackorgans beim Kaninchen. Biol. Untersuch., n. f. 17, 1912: 72-113

ROOSS, M. H.-REITH, E. J.: Histology a Text and Atlas. Harper \& Row, Publishers, J. B. Lippincott company, New York, Cambridge, Philadelphia, San Francisco, London, 1985, pp. $400-403$

SCHULZE, F. E.: Über die becherförmigen Organe der Fische. Z. wissensch. Zool., 12, 1863: $218-292$

SCHWALBE, G.: Über die Geschmacksorgane der Säugetiere und des Menschen. Arch. mikr. Ant., 4., 1868: 154-210

SMOLICH, A.-MICHEL, G.: Mikroskopische Anatomie der Haustiere. VEB Gustav Fischer Verlag Jena, 1985, pp. 91-94, pp. 363-364

SPOENDLIN, H.: Taste buds. In: (ed. by) A. Bischoff: Ultrastructure of the peripheral nervous system and sense organs. Stuttgart, Georg Thieme Verlag, 1970, pp. 326-337

TAKEDA, M.: Fine structure of developing taste buds in human fetal circumvallate papillae (in Japanese with Euglish summary). Acta anat. nippon., 47, 1972: 325 - 337 
TAKEDA, M.: An electron microscopis study on the innervation in the taste buds of the mouse circumvallate papillae. Arch. histol. jap., 39, 1976: 257-269

TAKEDA, M. - HOSHINO, T.: Fine structure of taste buds in the rat. Arch. histol. jap., 37, 1975: $395-413$

TICHY, F.-CERNY, H.: The morphogenesis of circumvallate papillae and differentiation of taste buds in sheep ontogeny. Acta vet. Brno, 56, 1987: 261-274

TRUJILLO-CENOZ, O.: Electron microscope study of the rabbit gustatory bud. Z. Zellforsch., 46, 1957: $272-280$

UGA, S.: The fine structure of gustatory receptors and their synapses in frog's tongue. Symp. Cell Chem., 16, 1966; 75-86

UGA, S.: A study on the cytoarchitecture of taste buds of rat circumvallate papillae. Arch, histol. jap., 31, 1969; 59-72

WHITESIDE, B.: The regeneration of the gustatory apparatus in the rat. J. comp. Neurol., 40, 1927: $33-45$ 
Plate I.

Tichý F.: The Morphogenesis of Circumvallate Papillae ... pp. 99-100.

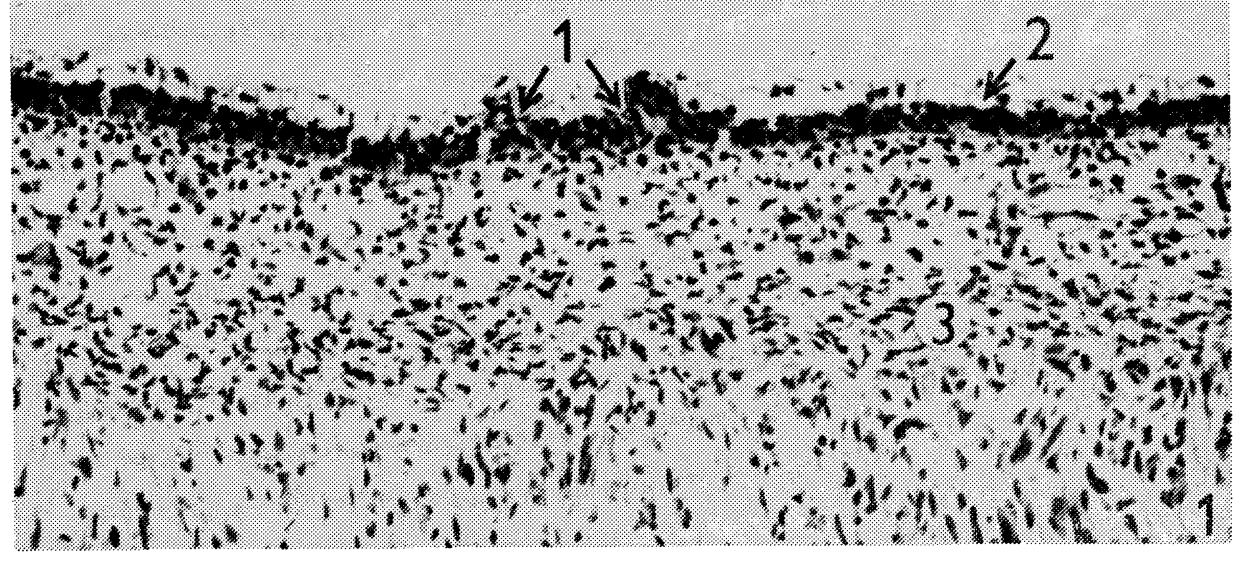

Fig. 1: A part of the lingual surface of a porcine foetus at 41 days. Simple elevations on the dorsum linguae (1). The surface layer of poorly-stained cells of the epithelium (2). Thickening connective tissue as a rudiment of the aponeurosis linguae (3). Haematoxylin-eosin (HE); magnification: $\times 250$.

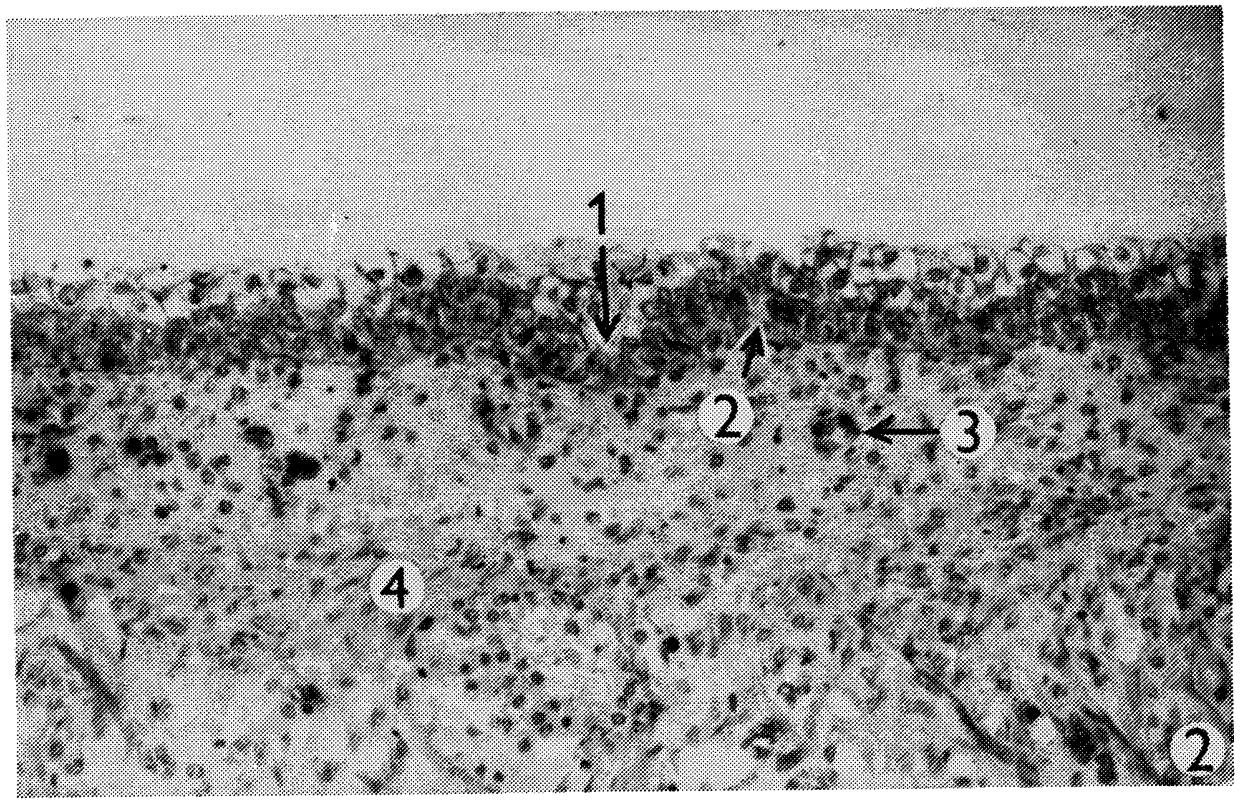

Fig. 2: A part of the lingual surface of a porcine foetus at 44 days. A developing cell band (1) as the basis of the furrow encircling the circumvallate papilla. A light cell in the germinative layer of the epithelium (2), bordered by well-stained cells with elongated nuclei. A capillary in the layer of mucosal connective tissue (3). The rudiment of the aponeurosis linguae (4). HE, magnification: $\times 250$. 
Plate II.

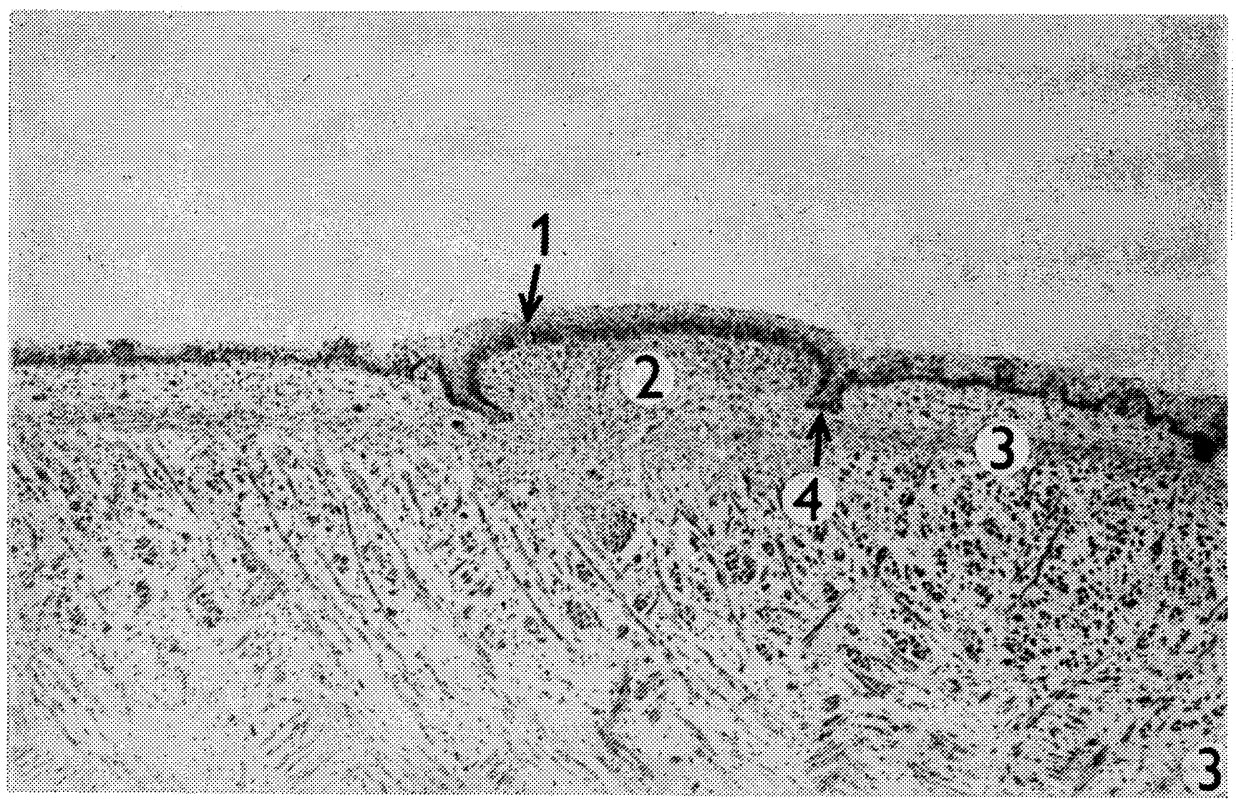

Fig. 3: A forming circumvallate papilla on the tongue of a porcine foetus at 50 days (2). A taste bud at the early stage of differentiation on the dorsal surface of the papillary anlage (1). The anlagen of ducts of the gll. gustatoriae (4). The developing aponeurosis linguae (3). HE, magnification: $\times 100$.

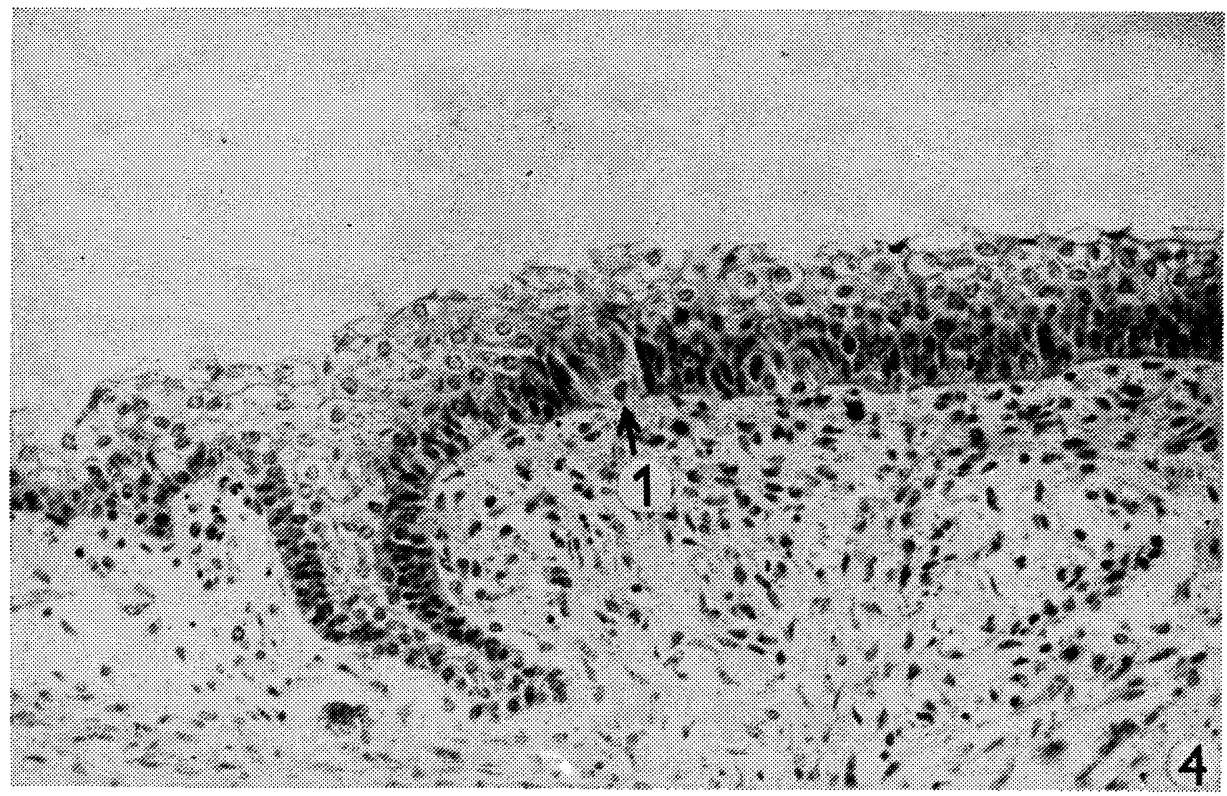

Fig. 4: A detail of a differentiating taste bud (1) in the epithelium of the dorsal surface of the anlage of a circumvallate papilla in a 50-day-old porcine foetus. HE, magnification: $\times 400$. 


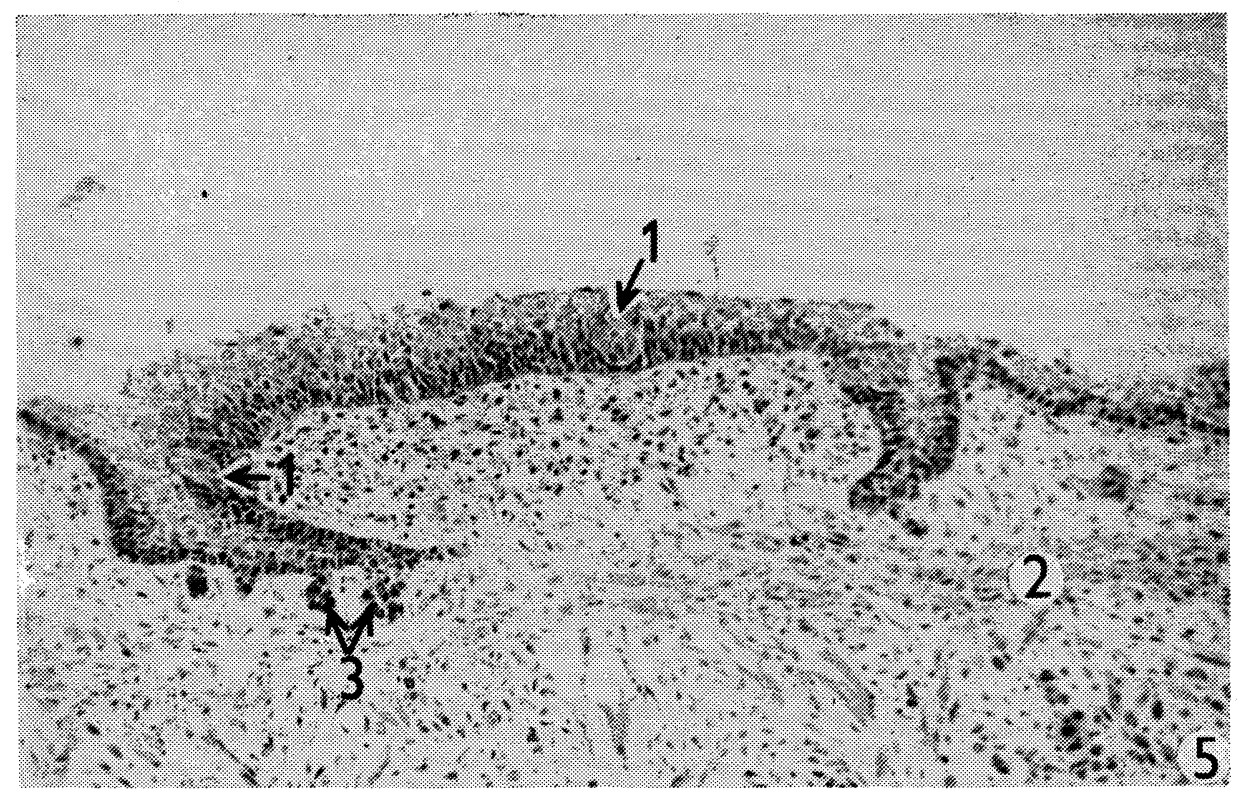

Fig. 5: The anlage of a circumvallate papilla on the tongue of a porcine foetus at 53 days. Taste buds forming on both the dorsal and lateral surfaces of the papilla (1). The rudiment of the aponeurosis linguae in the layer of mucosal connective tissue (2). Differentiating ducts of the gll. gustatoriae (3) $\mathrm{HE}$, magnification: $\times 250$.

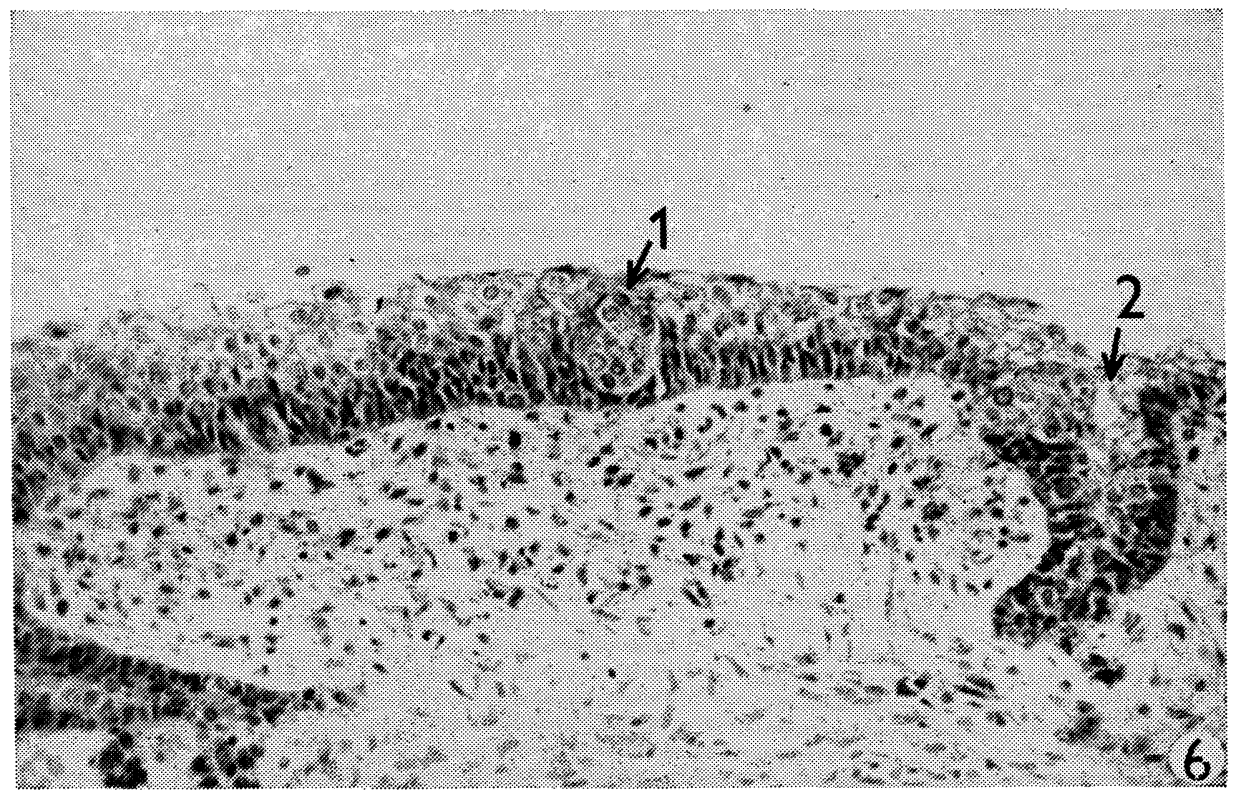

Fig. 6: A part of the anlage of a circumvallate papilla with a developing taste (1) bud in the lingual epithelium of a 53-day-old porcine foetus. An indication of the cleft in the compact cell band (2) in the process of encircling furrow formation. HE, magnification: $\times 400$. 
Plate IV.

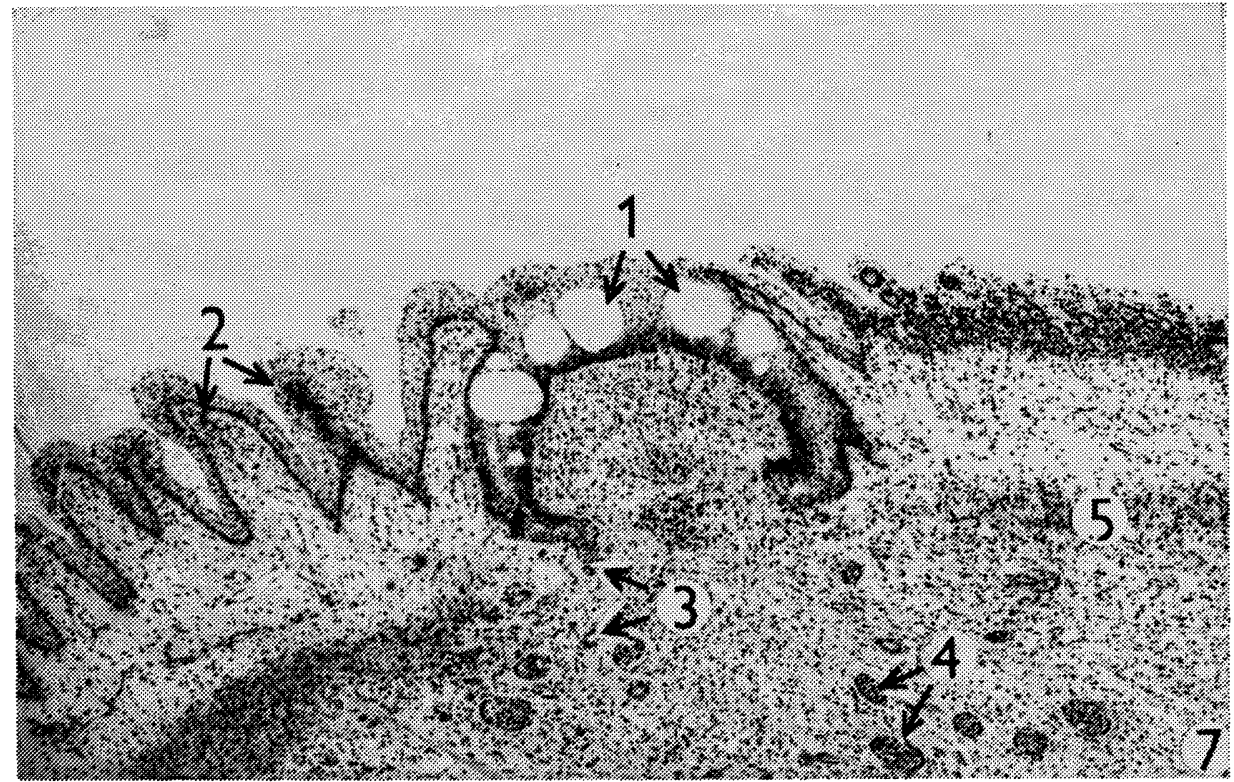

Fig. 7: The lingual surface of a porcine foetus at 57 days. A differentiating circumvallate papilla with spaces of different sizes in the epithelium (1), surrounded with undifferentiated anlagen of other lingual papillae (2). Cross-sectioned lumina of gustatory gland ducts (3) and the indication of secretory regions (4). The aponeurosis linguae (5) is missing under the base of the circumvallate papilla. HE, magnification: $\times 100$.

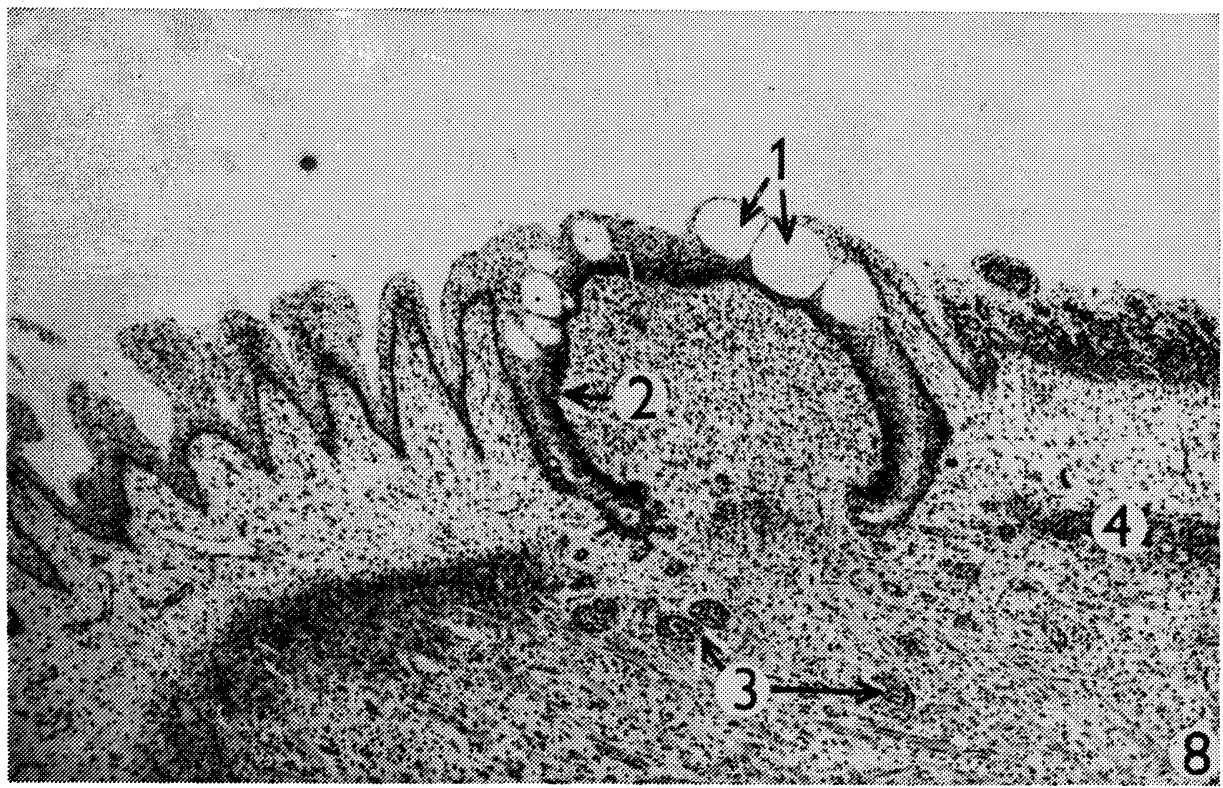

Fig. 8: A developing circumvallate papilla with the spaces in the epithelial basis of the encircling furrow (1) and differentiating taste buds in the wall epithelium (2) in a 57-day-old porcine foetus. In the connective tissue and lingual musculature, regions of the developing gustatory gland (3) can be seen. The aponeurosis linguae (4). HE, magnification: $\times 100$. 
Plate V.

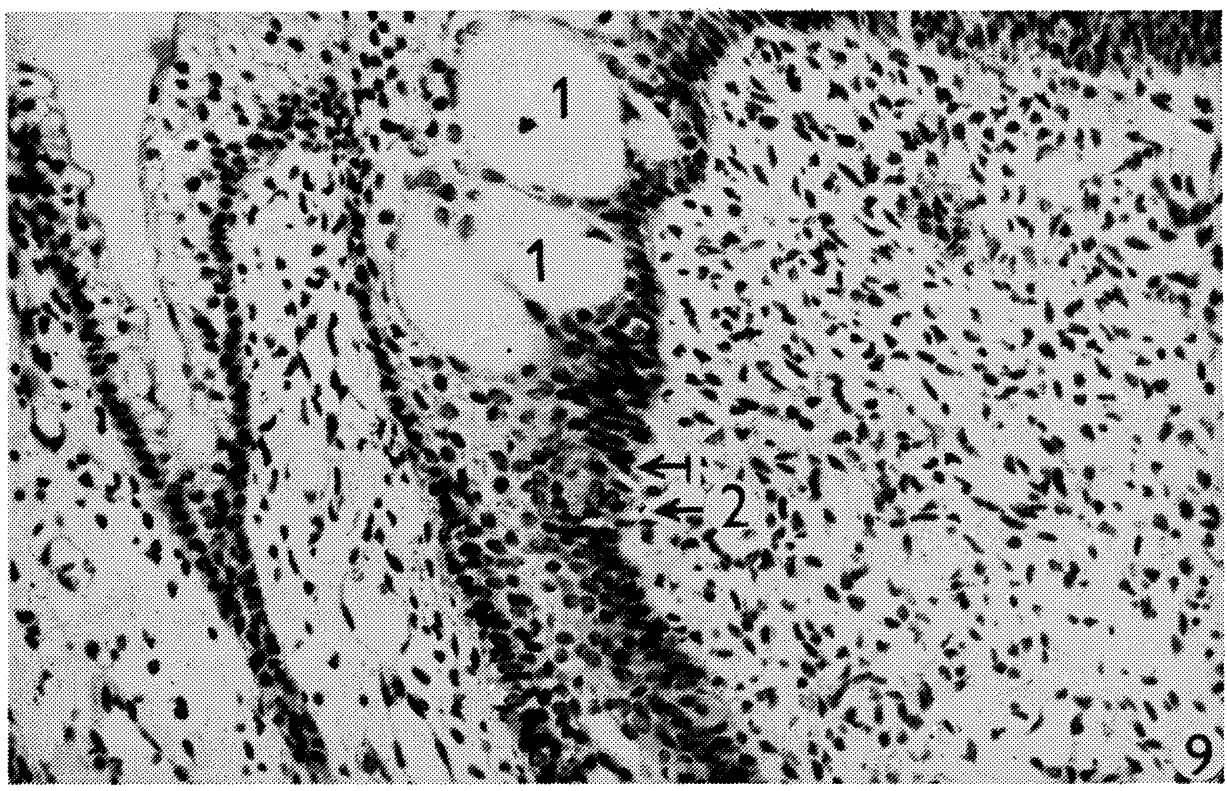

Fig. 9: A detail of Fig. 8. Spaces in the epithelial basis of the encircling furrow (1). A differentiating taste bud (2). Two types of nuclei in cells of the bud. Elongated nuclei of pericanalicular cells $(\rightarrow)$. HE, magnification: $\times 400$.

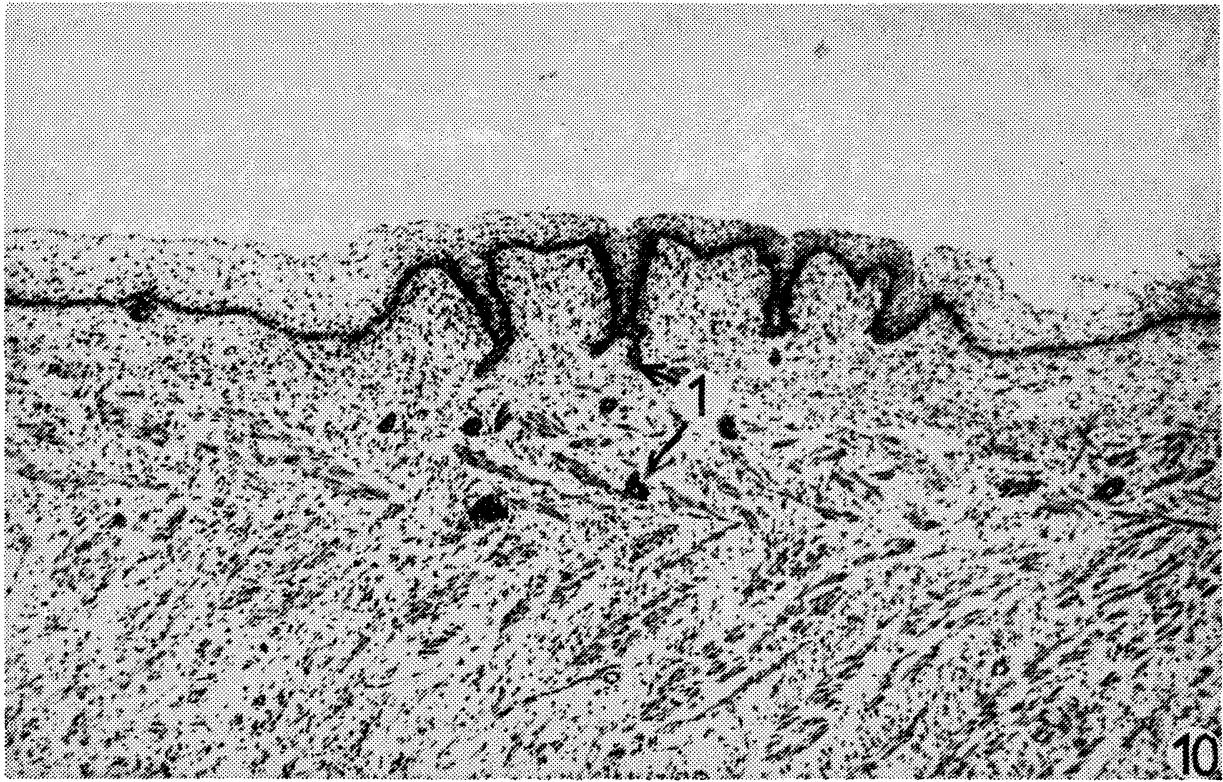

Fig. 10: The composite anlage of a circumvallate papilla in a porcine foetus at 57 days. Sections through the lumina of gustatory gland ducts (1) in the connective tissue. HE, magnification: $\times 100$. 


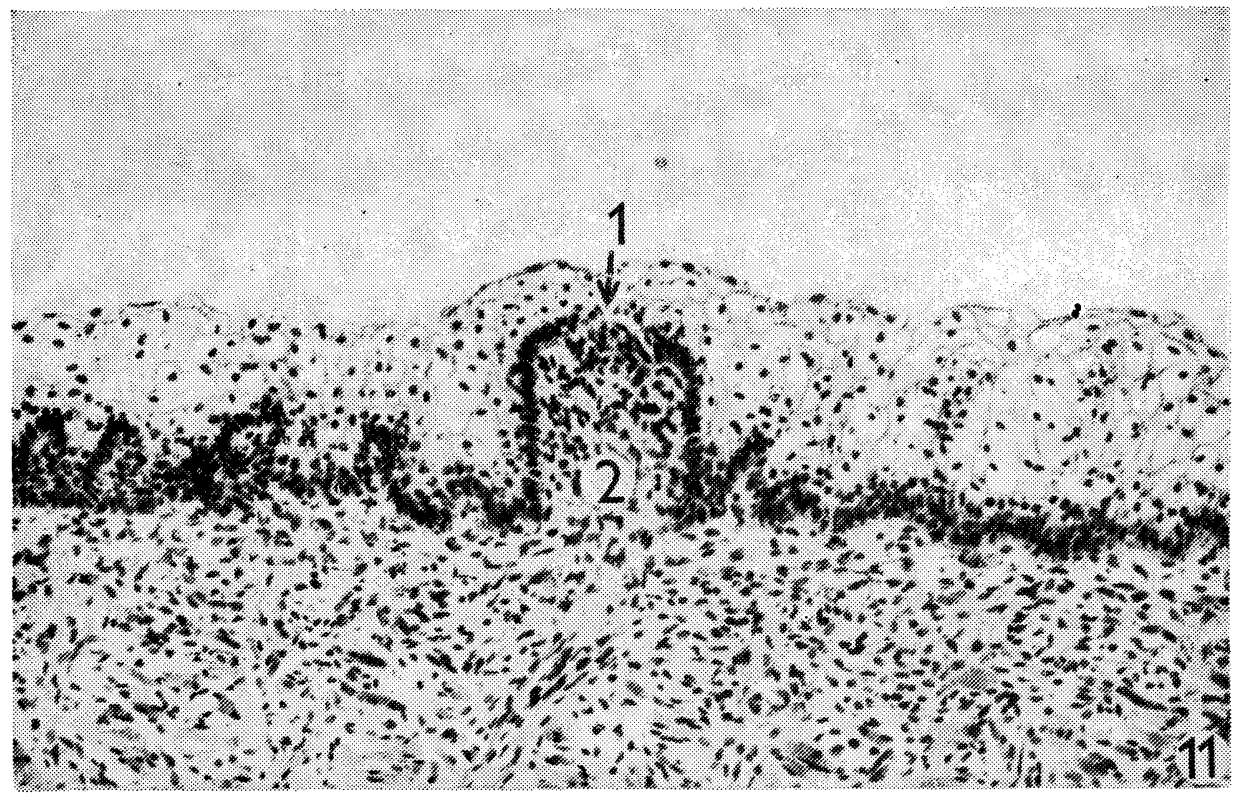

Fig. 11: The surface of the lateral part of the tongue in a 57-day-old porcine foetus. The anlage of a foliate papilla (2) with a developing taste bud (1). HE, magnification: $\times 250$.

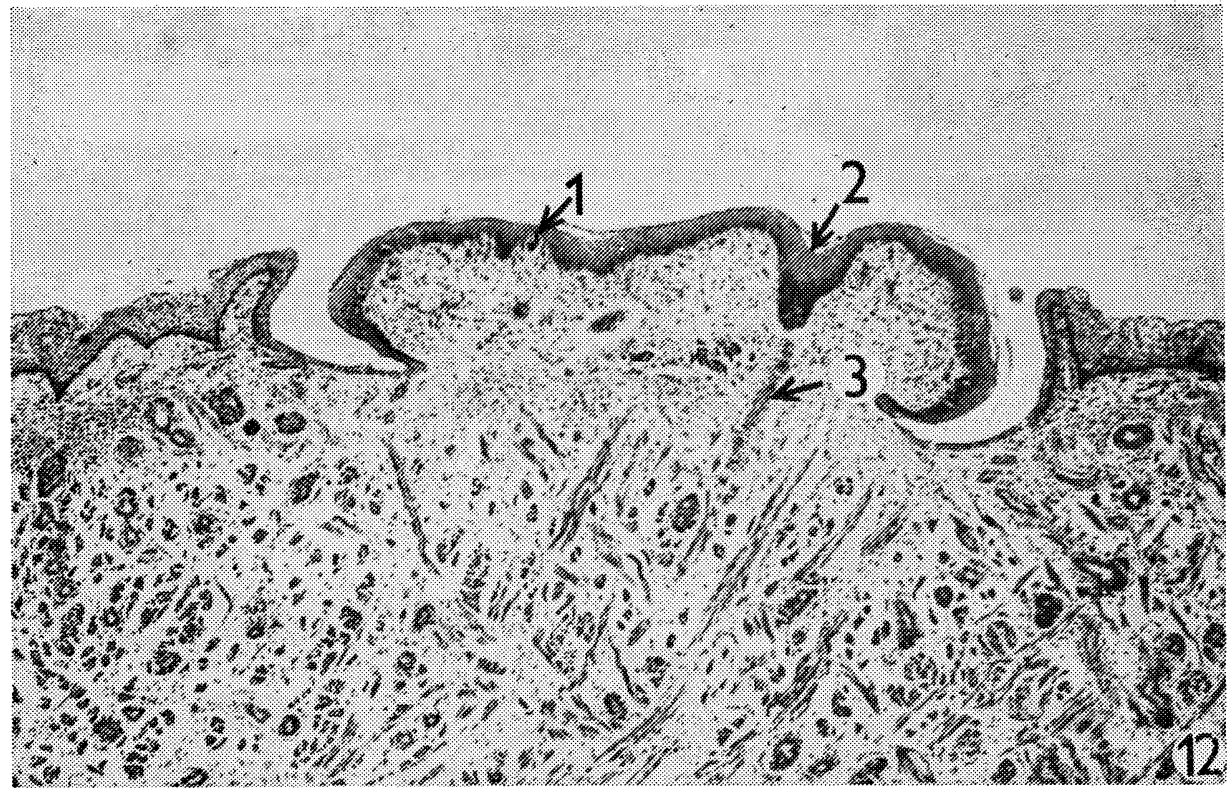

Fig. 12: A circumvallate papilla in a porcine foetus at 64 days. The dorsal surface shows occasional taste buds (1) and depressions (2) varying in depth. Ducts of the gustatory gland (3) open into the depressions. HE, magnification: $\times 100$. 


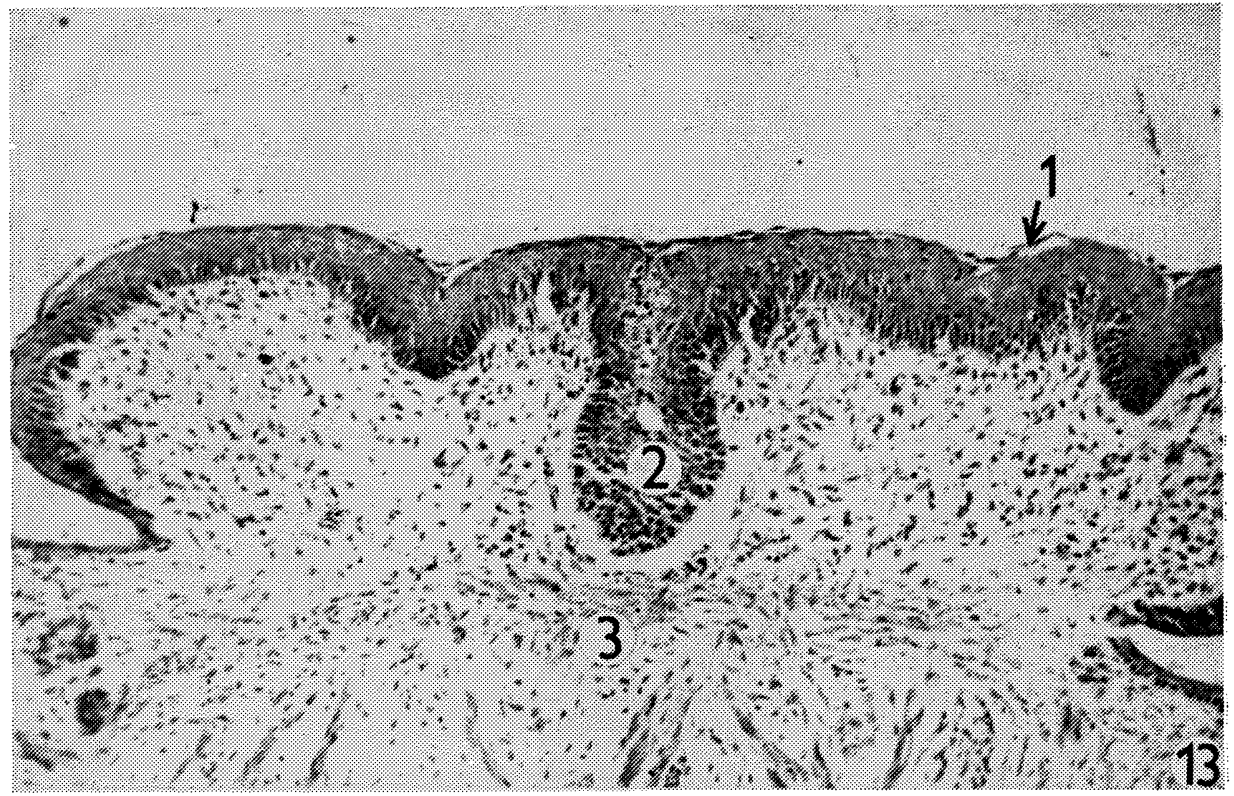

Fig. 13: A part of the circumvallate papilla of the 64-day-old porcine foetus. The epithelial surface is covered with a layer of keratinized cells (1). The epithelial bands extend into the connective stroma of the papilla (2) as remnants of the composite anlage. An inconspicuous dense connective tissue layer under the base of the papilla (3). HE, magnification: $\times 250$.

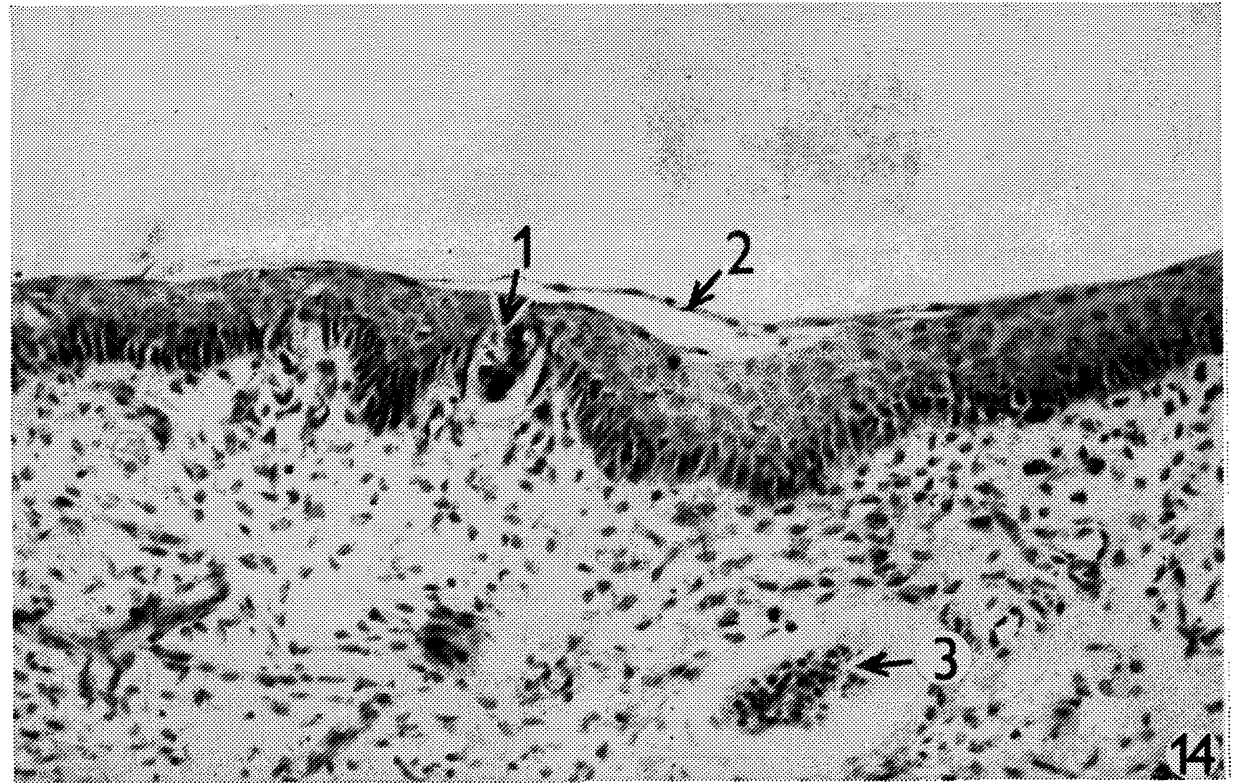

Fig. 14: An area of the dorsal surface of the circumvallate papilla at 64 days. A taste bud (1). A layer of keratinized cells on the epithelial surface (2). The connective stroma contains noduli of lymphoreticular tissue (3). $\mathrm{HE}$, magnification: $\times 400$. 


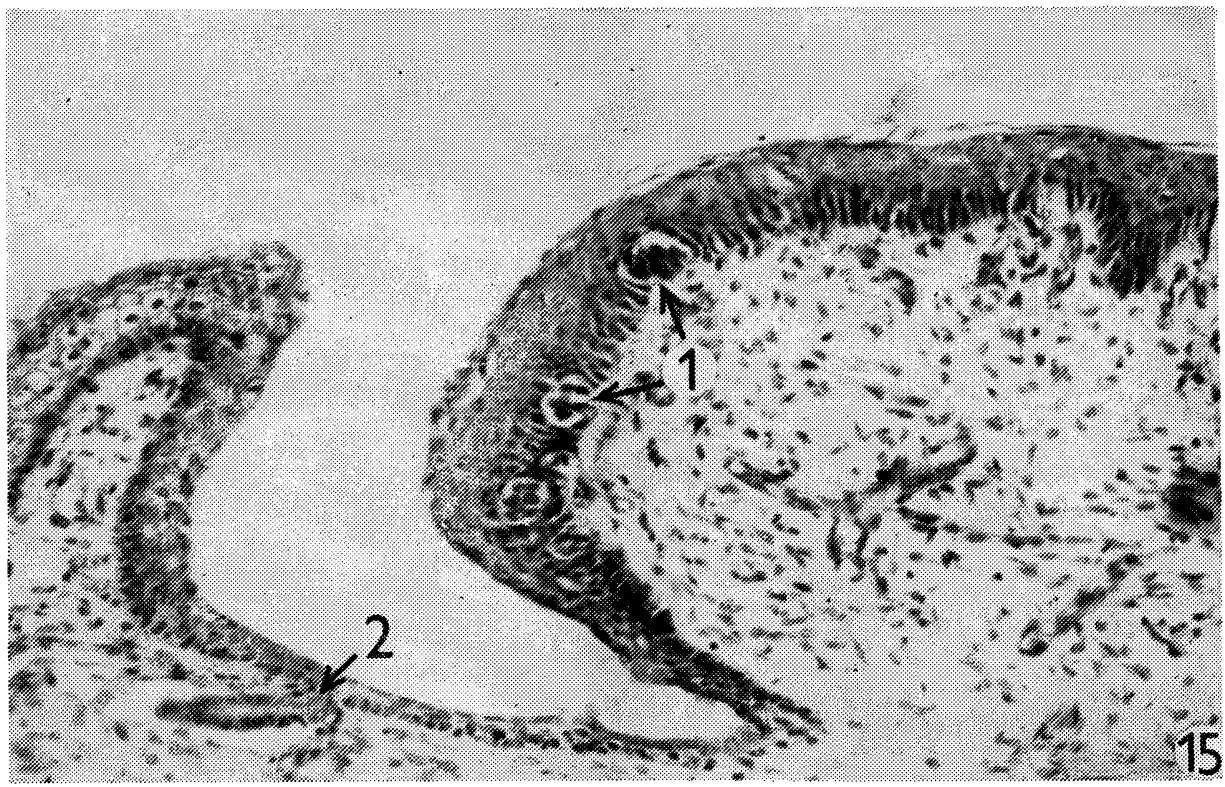

Fig. 15: A part of the circumvallate papilla at 64 days. The wall epithelium shows numerous taste buds (1). Ducts of the gustatory glands (2) open onto the bottom of the encircling furrow. $\mathrm{HE}$, magnification: $\times 400$.

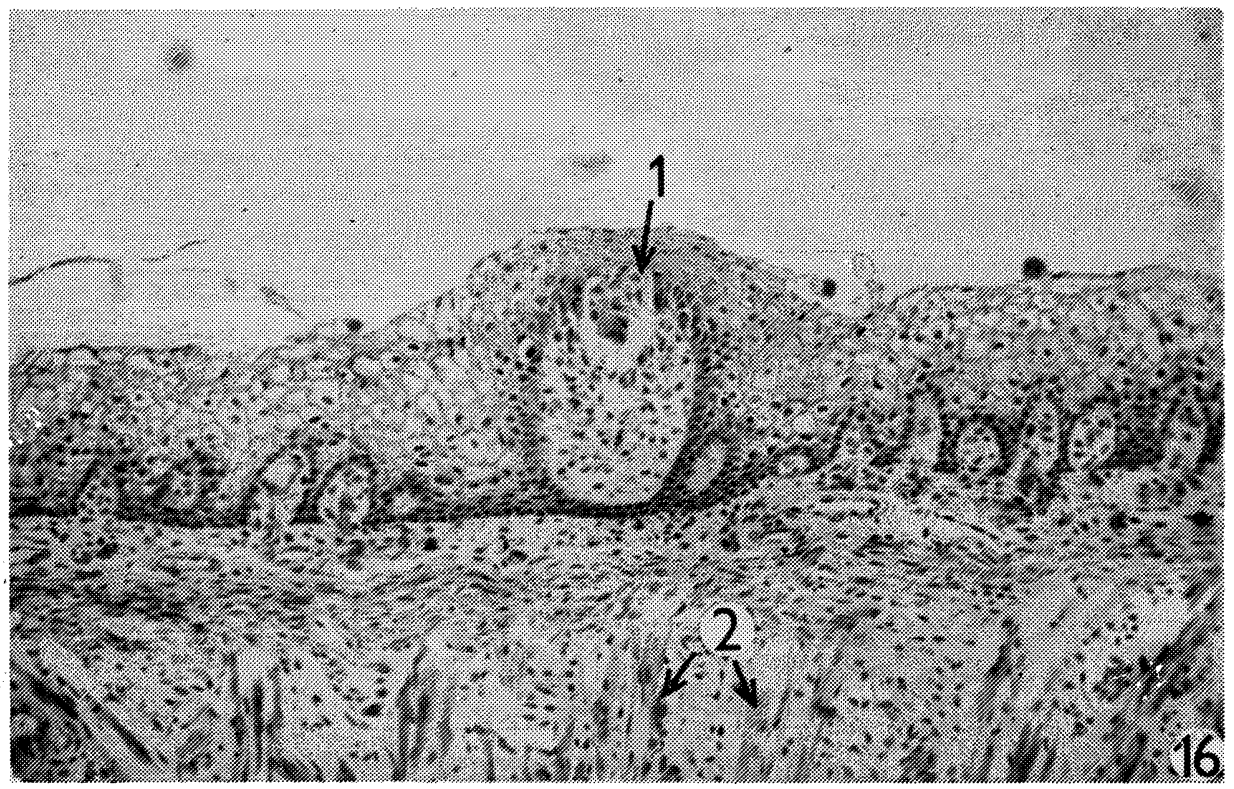

Fig. 16: The surface of the lateral part of the tongue at 64 days. A developing foliate papilla with a taste bud (1) in the dorsal epithelium. Fasciculi in the process of organization (2). HE, magnification: $\times 250$. 